\title{
UDC 631.5:635.531
}

\section{EFFICIENCY OF SEEDLINGS CULTIVATION OF CELERY SALAD IN THE USE OF HYDRO- GEL}

\author{
Ulianych O.I., Kovtunyuk Z.I., Vorobiova N.V., Didenko I.A., Yatsenko V.V. \\ Uman National University of Horticulture \\ Instutytska str., 1, Uman, Cherkasy region, Ukraine, 20305 \\ E-mail:ecodidenko@gmail.com \\ https://doi.org/10.32717/0131-0062-2019-65-50-57
}

The aim of the research. To study the influence of different forms of hydrogel on growth, development of seedlings, and also the quality of leafstalks and the total yield of celery salad in open soil. The most optimal conditions establish for the growth and development of seedlings of celery salad. The morphological and biological characteristics of celery salad determine which will determine its marketable quality; to establish the total productivity of celery salad, depending on the method of growing seedlings; to pick up the optimal forms of hydrogel for growing seedlings of celery salad. Methods. Field methods, laboratory-field methods, statistical methods. Results. The influence of hydrogel on growing of celery salad seedlings in the conditions of the Right Bank Forest-Steppe of Ukraine was determined for the first time. It ware found that the use of different forms of hydrogel positively affects for the growth, development, the basic phenological phases, the total and commercial yield of celery salad. Conclusions. It was proved that variants using all forms of hydrogel had better height $(+0.2-6.0 \mathrm{~cm}$ to control), the thickness of the root $(+2.0-3.8 \mathrm{~mm}$ to control) and mass of the aboveground part $(+0.5-1.6 \mathrm{~g}$ to control) than the control variant without the use of hydrogel. It was establish that the use of hydrogel during the cultivation of celery salad positively influenced the biometric indices of the plant and its yield. Thus, the use of hydrogel in the form of gel in the Anita variety helped to obtain $23.7 \mathrm{t} / \mathrm{ha}$ of high quality commercial products, which was an additional $6.9 \mathrm{t} / \mathrm{ha}$ before control. The yield of crops of Anita variety was higher in variants using gel (23.7 t/ha) and tablets (21.9 t/ha), which was 6.9 and $5.1 \mathrm{t} / \mathrm{ha}$ more than the control version. Below was the variant without introducing hydrogel $-17.5 \mathrm{t} / \mathrm{ha}$. In addition, the yield level indicator had a strong direct correlation with the length and thickness of the petiole, the total and mass of the product. Found that the use of hydrogel was cost effective and cost effective. The best profitability was note with the use of gel in the variety Anita $-55.3 \%$.

Key words: celery salad, hydrogel, gel, granules, tablets, yield, correlation connections

\section{ЕФЕКТИВНІСТЬ ВИРОЩУВАННЯ РОЗСАДИ СЕЛЕРИ ЧЕРЕШКОВОЇ ЗА ЗАСТОСУВАННЯ ГІДРОГЕЛЮ}

\author{
Улянич О.І., Ковтунюк 3.І., Воробйова Н.В., Діденко І.А., Яценко В. В. \\ Уманський національний університет садівництва, Умань, Україна \\ вул. Інститутська, 1, м. Умань, Черкаська область, Україна, 20305 \\ E-mail: ecodidenko@gmail.com
}

Мета. Вивчити вплив різних форм гідрогелю на ріст, розвиток розсадних рослин, а також на якість черешків та загальну врожайність селери черешкової у відкритому грунті; встановити найбільш оптимальні умови для росту та розвитку розсади селери черешкової; визначити морфологічні та біологічні ознаки продуктових органів селери черешкової, які визначають іiї товарну якість; встановити сумарну продуктивність селери черешкової залежно від способу вирощування розсади; підбір оптимальних форм гідрогелю для вирощування розсади селери черешкової. Методи. Польові, лабораторно-польові, статистичні. Результати. Уперше в умовах Правобережного Лісостепу України було проведено дослідження з визначення впливу застосування гідрогелю під час вирощування розсади селери черешкової. Виявлено, що використання різних форм гідрогелю позитивно впливає на ріст, розвиток, швидкість проходження основних фенологічних фаз, загальну та товарну врожайність селери черешкової. Висновки. Доведено, що варіанти з використанням усіх форм гідрогелю мали кращі показники висоти $(+0,2-6,0$ см до контролю), товщини кореневої шийки $(+2,0-3,8$ мм до контро- 
лю) та маси надземної частини (+0,5-1,6 г до контролю), ніж контрольний варіант без використання гідрогелю. Установлено, що застосування гідрогелю під час вирощування селери черешкової позитивно впливає на біометричні показники рослини та рівень ії врожайності. Так, використання гідрогелю у формі гелю в сорту Аніта допомогло отримати 23,7 т/га якісної товарної продукції, а це додатково 6,9 т/га до контролю. Урожайність рослин селери сорту Аніта була більшою у варіантах із застосуванням гелю $(23,7$ т/га) та таблеток $(21,9$ т/га), що на 6,9 та 5,1 т/га більше за контрольний варіант, а нижчою у варіанті без внесення гідрогелю - 17,5 т/га. Крім того, показник рівня врожайності має сильну пряму кореляційну залежність 3 довжиною та товщиною черешка, загальною та товарною масою. Виявлено, що використання гідрогелю $є$ економічно ефективним та рентабельним. Кращою рентабельністю можна відмітити варіант із використанням гелю у сорту Аніта - 55,3\%.

Ключові слова: селера черешкова, гідрогель, гель, гранули, таблетки, урожайність, кореляційні зв'язки

Актуальність. Потреба у збільшенні виробництва сільськогосподарської продукції з огляду на зниження якості оброблюваних земель та зміни клімату як більш посушливого, виявляе неабиякий інтерес до винайдення нових матеріалів для внесення в грунт, які забезпечували б рослину необхідною кількістю вологи та мали тривалий термін дії (Bolotskykh, A.S., 2005; Ulyanych, O.I., 2018; Pressman, E., 1997).

Одним зі способів досягнення цієї мети у сільському господарстві $\epsilon$ використання водоакумулюючих речовин, наприклад, гідрогелю. Гідрогель у своїй основі $є$ водопоглинаючим полімером, молекули якого зв'язуються з молекулами води (Ulyanych, O. I., 2018). Сільськогосподарські гідрогелі називають гранулами для утримання води, оскільки вони значно збільшуються в розмірі, коли стикаються 3 водою (Ramin, A. A., 1991).

Гідрогель $є$ відносно новим та маловивченим в Україні елементом технології вирощування сільськогосподарських культур загалом та овочевих рослин зокрема. Тому застосування його під час вирощування овочів $\epsilon$ надзвичайно актуальним.

Селера черешкова (Apiumgraveolens L. var. dulce) є рослиною, яка для свого росту та розвитку потребує достатньої кількості вологи (Borosic, J., 1990). Проте, іiі коренева система є недостатньо розвинутою та чутливою до коливань вологості, а це (як наслідок) призводить до появи тріщин у черешках, тобто погіршення якості сировини.

Аналіз останніх досліджень і публікацій 3 досліджуваної теми. Останніми роками розробленням питань технології вирощування селери присвячено роботи, авторами яких є: Т.К. Горова, В.В. Хареба, О.І. Улянич, С.А. Вдовенко, І.В. Дидів， О.Й. Дидів， З.Д. Сич， І.М. Бобось, Т.В. Мельниченко, Е. Костерна, А. Занієвич-
Байковська, Р. Роса. Досягнення аграрної науки, широкі можливості розвитку овочівництва, забезпеченість галузі фахівцями, дозволяють вирощувати селеру черешкову. Однак, широке iii впровадження у виробництво стримується відсутністю зональної науково обгрунтованої технології вирощування, де особливу увагу слід приділити елементам, що сприятимуть формуванню високого рівня врожайності і якості (Ulyanych, O.I., 2018, Markovic, P., 1992, Kastori, R., 1991).

Мета досліджень - вивчити вплив різних форм гідрогелю на ріст, розвиток розсадних рослин, а також на якість черешків та загальну врожайність селери черешкової у відкритому грунті.

Матеріал і методи досліджень. Дослідження проводили відповідно до загальноприйнятих національних методик і стандартів. Досліди закладали згідно 3 „Методикою дослідної справи в овочівництві і баштанництві”. Елементи технології вирощування селери черешкової - загальноприйняті для Правобережного Лісостепу України.

Вирощування розсадних рослин селери черешкової за застосування гідрогелів вивчали в умовах НВВ Уманського НУС. У своїх дослідженнях використовували сорти селери черешкової, внесені до Державного реєстру сортів рослин, придатних для поширення в Україні: Діамант та Аніта. Сорт Діамант - універсальний високоврожайний сорт селери черешкової. Він формує середнього розміру листки, 3 товсті (3-4 см біля основи), черешки мають насичений темно-зелений колір. Сорт Аніта - середньостиглий сорт селери черешкової 3 потужною прямостоячою розеткою. Він формує щільні зімкнуті черешки, довжина яких сягає 2530 см, а ширина $-3,5-4,5$ см.

У ході досліджень були вивчені варіанти із застосуванням гідрогелю фірми Максимарін у формі гелю, гранул та таблеток. До чарунок касети роз- 
мірами $4 \times 4$ см та об'ємом чарунок 25 см $^{3}$ вносили 4-5 г гелю, таку ж кількість гранул та 1 таблетку. Кількість гідрогелю не перевищувала 20-25\% від загального об'єму чарунки. У варіанті контроль гідрогель не застосовували.

Висаджування рослин у відкритий грунт проводили у віці розсади 60-65 діб. Схема розміщення рослин $45 \times 20 \mathrm{~cm}$, що відповідає густоті 111 тис. шт. росл./га. Закладання досліду проводилося у чотириразовій повторності. Загальна площа дослідної ділянки - $20 \mathrm{~m}^{2}$, площа облікової - $15 \mathrm{~m}^{2}$.

Вирощували розсадні рослини в касетах із розміром чарунок $4 \times 4 \mathrm{~cm}$. Попередньо дезинфіковані касети, заправляли поживною сумішшю 3 торфу $(60 \%)$, дернового грунту (30\%) та перегною (10\%). У фазу першого справжнього листка проводили пікірування сіянців. Температурний режим підтримували вдень: $20 \ldots 22^{\circ} \mathrm{C}$; вночі: $14 \ldots 16^{\circ} \mathrm{C}$.

Збір даних фенологічних спостережень за рослинами проводили згідно методики, викладеної у працях В. Ф. Мойсейченка. Також відмічали дати висіву насіння, початок фенологічних фаз росту та розвитку рослин: появу поодиноких (15\%) і масових сходів (75-80 \%); формування першого та другого справжніх листків, початок утворення розетки та формування черешка, початок технічної стиглостi (Bondarenko, H.L., 2001; Hrytsayenko, Z.M., 2003).

Біометричні вимірювання були проведенні у повтореннях кожного варіанту досліду. Проводили вимірювання висоти розсадних рослин, а також кількості та довжини черешків після їх висаджування у відкритий грунт. Площу листка визначали методом «висічок» $\left(\mathrm{y} \mathrm{cm}^{2}\right)$. Облік врожаю здійснювали із кожної ділянки ваговим методом. Отримані дані у дослідах статистично оброблялись методами кореляційного та дисперсійного аналізу за допомогою пакету програм Microsoft Office. Згідно 3 технологічними картами та за фактичними матеріально-грошовими витратами розраховували економічну ефективність застосування елементів технології вирощування селери черешкової.

Результати досліджень. В умовах НВВ Уманського НУС розсаду черешкової селери вирощували у касетах, що передбачало собою сівбу насіння, який проводили у весняній теплиці в ранні строки - 3 III декади лютого - до I декади березня у посівні ящики і пікірування рослин зі шкілки сіянців, яке проводили 3 появою 1-го справжнього листка, у чарунки розмірами 4 x 4 см. Температурний режим підтримували в межах: вдень: $20 . .25^{\circ} \mathrm{C}$, вночі: $16 \ldots 18^{\circ} \mathrm{C}$.

Упродовж досліджень нами було зафіксовано кількість діб від повних сходів до початку окремих фенологічних фаз росту та розвитку черешкової селери. У сорту Діамант, у середньому за 20172018 роки досліджень, повні сходи спостерігали на 8 добу, а наявність першого справжнього листка на 15-17 добу. Період розвитку сіянців у рослин сорту Аніта був дещо довшим: появу сходів спостерігали на 10 добу, у середньому за роки досліджень, а появу 1-го справжнього листка - на 20 добу у 2017 і на 23 добу у 2018 році (табл. 1).

Таблиця 1 - Кількість діб від повних сходів до наявності 1-го справжнього листка у сіянців селери черешкової

\begin{tabular}{|c|c|c|c|}
\hline \multirow{3}{*}{ Сорт } & \multirow{2}{*}{ Рік } & \multicolumn{2}{|c|}{ Фаза росту й розвитку, діб } \\
\cline { 3 - 4 } & & $\begin{array}{c}\text { Повні сходи, } \\
\mathrm{M} \pm \mathrm{m}\end{array}$ & $\begin{array}{c}\text { Наявність } \\
\text { 1-го справжнього листка, } \mathrm{M} \pm \mathrm{m}\end{array}$ \\
\hline \multirow{3}{*}{ Діамант } & 2017 & $8 \pm 0,13$ & $15 \pm 0,13$ \\
\cline { 2 - 4 } & 2018 & $8 \pm 0,14$ & $15 \pm 0,15$ \\
\cline { 2 - 4 } & середнє за два роки & $8 \pm 0,13$ & $16 \pm 0,14$ \\
\hline \multirow{3}{*}{ Аніта } & 2017 & $9 \pm 0,09$ & $20 \pm 0,18$ \\
\cline { 2 - 4 } & 2018 & $11 \pm 0,10$ & $23 \pm 0,17$ \\
\cline { 2 - 4 } & середнє за два роки & $10 \pm 0,09$ & $21 \pm 0,17$ \\
\hline
\end{tabular}

Одразу після появи 1-го справжнього листка було проведено пікірування рослин. Послідуючі фази росту і розвитку, а саме: наявність 2-го справжнього листка, початок утворення розетки і формування черешків спостерігали у закритому грунті із застосуванням різних форм гідрогелю. У відкритому грунті відмічали фазу технічної стиглості черешка.
Початок утворення другого справжнього листка спостерігали на 24-27 добу в сорту Діамант (в контрольному варіанті і у варіанті із застосуванням таблеток, відповідно). Дещо раніше фаза наявності другого справжнього листка наставала в рослин селери черешкової сорту Аніта, а саме на 22-25 добу в середньому за роки досліджень. Фаза початку утворення розетки 
проходила майже одночасно по сортах та у варіантах досліду (28-30 доба). Початок формування черешка спостерігали тоді, коли рослини мали висоту 10-12 см. Кількість діб від висіву насіння до настання цієї фази була різною: в сорту Діамант у варіанті з внесенням гелю та гранул - 58-60 діб, що на 6-8 діб менше, ніж в контролі (без застосування гідрогелю). У рослин сорту Аніта фаза початку формування черешка наставала раніше, ніж в рослин селери сорту Діамант: на 55 добу у варіанті 3 внесенням гелю. У варіанті із застосуванням гранул та таблеток кількість діб була 59-61, відповідно.
Фазу технічної стиглості черешка спостерігали після висаджування рослин у відкритий грунт. У рослин сорту Аніта технічну стиглість відмічали раніше, ніж в сорту Діамант. У варіантах із застосуванням гранул та гелю вона становила 79-80 діб. У варіанті із застосуванням таблеток - 81 доба, що на 3 доби раніше, ніж у контрольному варіанті. У сорту Діамант фазу технічної стиглості також відмічали раніше у варіантах із застосуванням гелю та гранул: на 81-83 добу, що на 7-9 діб раніше, ніж у контролі (табл. 2).

Таблиця 2 - Кількість діб від повних сходів до настання окремих фенологічних фаз розвитку селери черешкової залежно від форми внесення гідрогелю (середнє за 2017-2018 рр.)

\begin{tabular}{|c|c|c|c|c|c|}
\hline ồ & Форма гідрогелю & $\begin{array}{c}\text { Наявність } \\
\text { 2-го справжньо- } \\
\text { го листка, } \mathrm{M} \pm \mathrm{m}\end{array}$ & $\begin{array}{c}\text { Початок } \\
\text { утворення } \\
\text { розетки, } \\
\mathrm{M} \pm \mathrm{m}\end{array}$ & $\begin{array}{c}\text { Початок форму- } \\
\text { вання черешка, } \\
\text { M } \pm \mathrm{m}\end{array}$ & $\begin{array}{c}\text { Технічна } \\
\text { стиглість } \\
\text { черешка, } \\
\mathrm{M} \pm \mathrm{m}\end{array}$ \\
\hline \multirow{4}{*}{ 嘼 } & Без гідрогелю (К)* & $24 \pm 0,15$ & $29 \pm 0,16$ & $67 \pm 0,26$ & $90 \pm 0,33$ \\
\hline & Гель & $25 \pm 0,13$ & $28 \pm 0,18$ & $59 \pm 0,25$ & $81 \pm 0,28$ \\
\hline & Таблетка & $27 \pm 0,15$ & $29 \pm 0,15$ & $64 \pm 0,25$ & $85 \pm 0,32$ \\
\hline & Гранули & $24 \pm 0,12$ & $30 \pm 0,17$ & $61 \pm 0,27$ & $83 \pm 0,30$ \\
\hline \multirow{4}{*}{$\cdot \stackrel{\Xi}{\mathbb{Z}}$} & Без гідрогелю & $23 \pm 0,11$ & $29 \pm 0,18$ & $62 \pm 0,16$ & $84 \pm 0,24$ \\
\hline & Гель & $25 \pm 0,15$ & $28 \pm 0,17$ & $55 \pm 0,19$ & $80 \pm 0,29$ \\
\hline & Таблетка & $25 \pm 0,16$ & $30 \pm 0,19$ & $61 \pm 0,20$ & $81 \pm 0,27$ \\
\hline & Гранули & $22 \pm 0,13$ & $27 \pm 0,19$ & $59 \pm 0,19$ & $79 \pm 0,24$ \\
\hline
\end{tabular}

Примітка: К* - контроль.

Висота рослини є показником, що характеризує умови іiі росту і розвитку, зокрема це забезпеченість поживними речовинами та вологою. Аналізуючи отримані дані можна відмітити, що, у середньому за 2017-2018 роки досліджень, показники висоти розсадних рослин коливались від 12,8 см - у сорту Діамант у варіанті із застосуванням таблеток, до 19,6 см - у сорту Аніта у варіанті із застосуванням гелю (табл. 3).

Показники товщини кореневої шийки розсадних рослин селери черешкової не істотно відрізнялись за варіантами досліду. Так, нижчими вони були у контрольному варіанті - 6,1 мм, а більшими - в усіх інших варіантах та сортах (8,1-9,9 мм). Кількість листків була наступною: менша у варіантах із застосуванням гелю та гранул (сорт Діамант) - 6,6 шт./росл., що на 1,5 шт./росл. менше, ніж у контролі, а більша у варіанті зі внесенням таблеток та гелю у сортах Діамант та Аніта - 9,5 шт./росл. (+1,4 шт./росл. до контролю).
Маса надземної частини рослини також $\epsilon$ одним із важливих показників ростових процесів, що значно впливає на врожайність рослин. Дані показники були дещо нижчими у варіантах без внесення гідрогелю у обох сортів, а також у варіанті із внесенням таблеток у сорту Діамант (1,4-1,9 г). Вищі показники маси рослин було відзначено у варіантах зі внесенням гелю та гранул у сорту Аніта - 3,0 та 2,7 г, відповідно, що на 1,3-1,6 г більше від контролю.

Після висаджування розсадних рослин у відкритий грунт було проаналізовано показники довжини черешка, їх товщину та кількість (як показники, які $\epsilon$ визначальними у визначенні врожайності селери черешкової).

Довжина черешка у рослин сорту Діамант у середньому за 2017-2018 роки досліджень коливалась від 25,5 см (у контролі) до 30,9 см (у варіанті із застосуванням таблеток). У рослин сорту Аніта довжина черешка була нижчою у варіанті без застосування гідрогелю - 26,5 см, а вищою у варіанті із застосуванням гелю - 31,6 cM. 
Таблиця 3 - Біометричні показники розсадних рослин селери черешкової залежно від форми застосування гідрогелю перед висаджуванням у відкритий грунт (середнє за 2017-2018рр.)

\begin{tabular}{|c|c|c|c|c|c|c|c|c|c|}
\hline 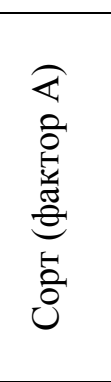 & 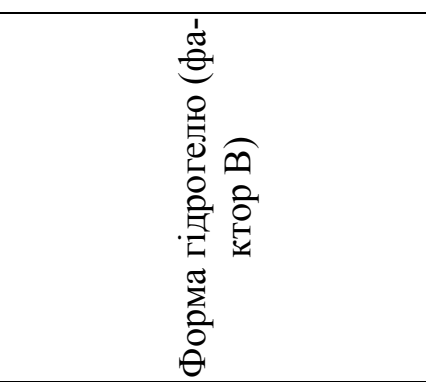 & 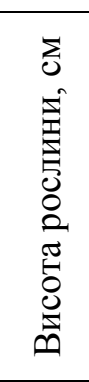 & 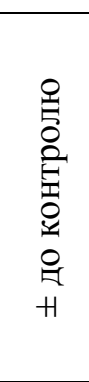 & 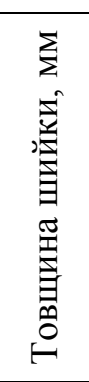 & 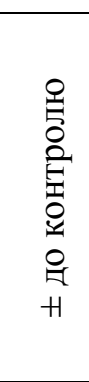 & 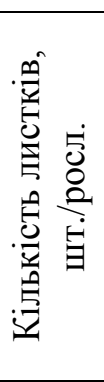 & 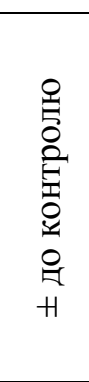 & 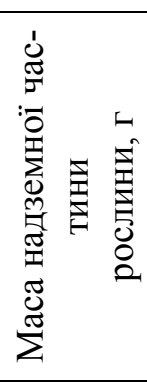 & 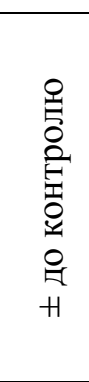 \\
\hline \multirow{4}{*}{ 䔍 } & Без гідрогелю (К)* & 13,5 & 0 & 6,1 & 0 & 8,1 & 0 & 1,4 & 0 \\
\hline & Гель & 13,7 & $+0,2$ & 9,9 & $+3,8$ & 6,6 & $-1,5$ & 2,5 & $+1,1$ \\
\hline & Таблетка & 12,8 & $-0,7$ & 8,1 & $+2,0$ & 9,5 & $+1,4$ & 1,9 & $+0,5$ \\
\hline & Гранули & 15,2 & $+1,7$ & 9,3 & $+3,2$ & 6,6 & $-1,5$ & 2,0 & $+0,6$ \\
\hline \multirow{4}{*}{ 息 } & Без гідрогелю & 15,2 & $+1,7$ & 9,1 & $+3,0$ & 8,5 & $+0,4$ & 1,9 & $+0,5$ \\
\hline & Гель & 19,6 & $+6,1$ & 8,9 & $+2,8$ & 9,5 & $+1,4$ & 3,0 & $+1,6$ \\
\hline & Таблетка & 16,5 & $+3,0$ & 9,5 & $+3,4$ & 8,7 & $+0,6$ & 2,6 & $+1,2$ \\
\hline & Гранули & 19,5 & $+6,0$ & 9,7 & $+3,6$ & 8,1 & 0 & 2,7 & $+1,3$ \\
\hline$H I P_{05}$ & $\begin{array}{r}\text { фактор } A \\
\text { фактор } B \\
\text { взаємодія } A B\end{array}$ & $\begin{array}{l}0,35 \\
0,49 \\
0,69\end{array}$ & - & $\begin{array}{l}0,36 \\
0,51 \\
0,72\end{array}$ & - & $\begin{array}{l}0,29 \\
0,41 \\
0,58\end{array}$ & - & $\begin{array}{l}0,10 \\
0,14 \\
0,19\end{array}$ & - \\
\hline
\end{tabular}

Примітка: $\mathrm{K}^{*}$ - контроль.

Показники товщини черешка у рослин сорту Діамант були вищими у варіанті із застосуванням гранул - 14,8 мм (+4,1 мм до контролю). У рослин селери сорту Аніта показники товщини черешка були вищими у варіанті із застосуванням гідрогелю у формі гелю - 15,8 мм (+5,1 мм до контролю), а нижчими - без використання гелю (11,1 мм) (табл. 4).

Під час обліку показника - кількість черешків на рослині - спостерігали певну залежність (чим більша кількість черешків, тим меншою $\epsilon$ їх товщина). Таким чином, кількість черешків у контрольному варіанті була найбільшою 19,5 шт./росл. У всіх інших варіантах досліду показник кількості черешків коливався від 15,3 шт./росл. у варіанті зі внесенням таблеток у сорту Діамант (-4,2 шт./росл. до контролю) до 18,3 шт./росл. - без застосування гідрогелю у сорту Аніта (-1,2 шт./росл. до контролю).

Застосування різних форм водоакумулюючих речовин загалом, та гідрогелю зокрема, під час вирощування селери черешкової істотно покращує якісні біометричні показники росту та розвитку рослин, а також позитивно впливає на загальний рівень врожайності.

Так, у середньому за два роки досліджень, загальна маса однієї рослини селери сорту Діамант становила від 613,6 до 693,3 г. Більшою вона була у варіанті із застосуванням гранул, а меншою - у контролі, відповідно. Товарна маса рослин даного сорту також була меншою у контролі - 371,1 г, а більшою у варіанті із застосуванням гранул - 436,0 г (+64,9 до контролю).

У варіантах досліду сорту Аніта загальна маса була наступною: у варіанті без застосування гідрогелю $-621,1$ г, (+ 7,5 г до контролю), у варіантах із внесенням гідрогелю - від 675,4 г до 711,5 г, що істотно перевищувало контроль на 61,8-97,9 г, відповідно.

Таку ж тенденцію у показниках спостерігали і з товарною масою рослин сорту Аніта: кращі - у інших варіантах із застосуванням різних форм гідрогелю - від 393,1 г за застосування таблеток, до 447,4 г за застосування гелю (від +22,0 до 76,3 г до контролю), гірші - у варіанті без застосування гідрогелю, а саме 363,2 г, що на 7,9 г менше контрольного варіанту (рис. 1).

Кращими показниками товарної врожайності відзначились варіанти із застосуванням гідрогелю. Так, урожайність селери сорту Діамант була вищою за використання гідрогелю у формі гранул (середнє за 2017-2018 рр.) - 22,3 т/га (+5,5 до контролю). Товарна врожайність у варіантах 3 використанням таблеток та гелю була практично однаковою - 20,9 та 21,0 т/га, що на 4,1 та 4,2 т/га більше за контрольний варіант (табл. 5). 
Таблиця 4 - Біометричні показники селери черешкової залежно від форми гідрогелю (середнє за 2017-2018 pp.)

\begin{tabular}{|c|c|c|c|c|c|c|c|}
\hline \multirow[b]{2}{*}{$\begin{array}{l}\text { a } \\
0 \\
0 \\
0 \\
\frac{0}{0} \\
0 \\
0 \\
0 \\
0 \\
0\end{array}$} & \multirow[b]{2}{*}{$\begin{array}{c}\text { Форма гідрогелю } \\
\text { (фактор В) }\end{array}$} & \multicolumn{6}{|c|}{ Показник } \\
\hline & & 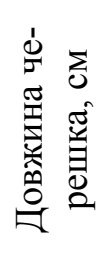 & 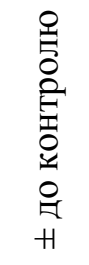 & 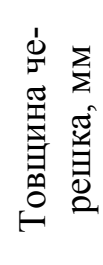 & 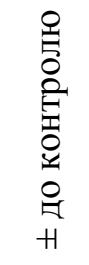 & 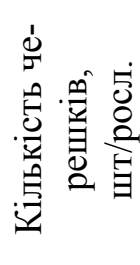 & 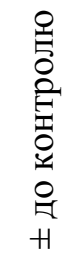 \\
\hline \multirow{4}{*}{ 䄰 } & Без гідрогелю (К)* & 25,5 & 0 & 10,7 & 0 & 19,5 & 0 \\
\hline & Гель & 28,0 & $+2,5$ & 13,9 & $+3,2$ & 15,7 & $-3,8$ \\
\hline & Таблетка & 30,9 & $+5,4$ & 12,7 & $+2,0$ & 15,3 & $-4,2$ \\
\hline & Гранули & 28,5 & $+3,0$ & 14,8 & $+4,1$ & 17,6 & $-1,9$ \\
\hline \multirow{4}{*}{ 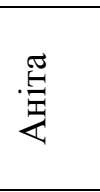 } & Без гідрогелю & 26,5 & $+1,0$ & 11,1 & $+0,4$ & 18,3 & $-1,2$ \\
\hline & Гель & 31,6 & $+6,1$ & 15,8 & $+5,1$ & 17,9 & $-1,6$ \\
\hline & Таблетка & 28,9 & $+3,4$ & 13,7 & $+3,0$ & 16,0 & $-3,5$ \\
\hline & Гранули & 29,5 & $+4,0$ & 15,1 & $+4,4$ & 16,5 & $-3,0$ \\
\hline$H I P_{05}$ & $\begin{array}{r}\text { фактор } A \\
\text { фактор } B \\
\text { взаємодія } A B\end{array}$ & $\begin{array}{l}1,24 \\
1,76 \\
2,49\end{array}$ & - & $\begin{array}{l}0,43 \\
0,61 \\
0,86\end{array}$ & - & $\begin{array}{l}0,79 \\
1,12 \\
1,59\end{array}$ & - \\
\hline
\end{tabular}

Примітка: $\mathrm{K}^{*}$ - контроль

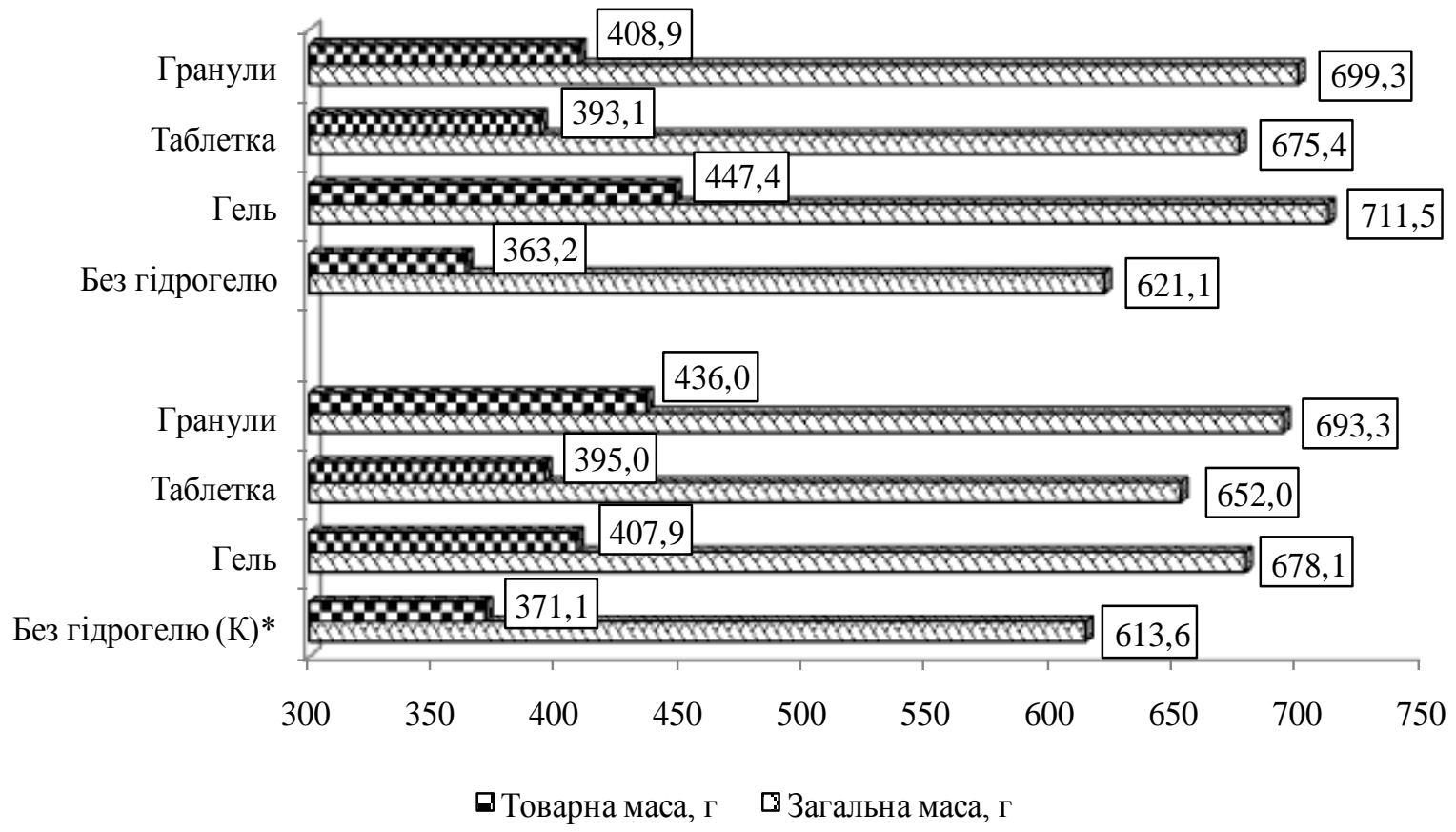

Рисунок 1. Загальна та товарна маса рослин селери черешкової, г 
Таблиця 5 - Товарна врожайність селери черешкової залежно від форми застосування гідрогелю, т/га

\begin{tabular}{|c|c|c|c|c|c|}
\hline \multirow{2}{*}{$\begin{array}{l}\text { Сорт (фак- } \\
\text { тор А) }\end{array}$} & \multirow{2}{*}{$\begin{array}{c}\text { Форма гідрогелю } \\
\text { (фактор В) }\end{array}$} & \multicolumn{3}{|c|}{ Урожайність, т/га } & \multirow{2}{*}{$\begin{array}{c} \pm \text { до конт- } \\
\text { ролю }\end{array}$} \\
\hline & & 2017 & 2018 & Середнє за два роки & \\
\hline \multirow{4}{*}{ Діамант } & Без гідрогелю (К)* & 15,6 & 18,0 & 16,8 & 0 \\
\hline & Гель & 20,2 & 21,8 & 21,0 & $+4,2$ \\
\hline & Таблетка & 22,7 & 19,1 & 20,9 & $+4,1$ \\
\hline & Гранули & 23,6 & 21,0 & 22,3 & $+5,5$ \\
\hline \multirow{4}{*}{ Аніта } & Без гідрогелю & 17,3 & 17,7 & 17,5 & $+0,7$ \\
\hline & Гель & 23,0 & 24,4 & 23,7 & $+6,9$ \\
\hline & Таблетка & 22,8 & 21,0 & 21,9 & $+5,1$ \\
\hline & Гранули & 20,6 & 21,4 & 21,0 & $+4,2$ \\
\hline$H I P_{05}$ & $\begin{array}{r}\text { фактор } A \\
\text { фактор } B \\
\text { взаємодія } A B\end{array}$ & $\begin{array}{l}0,75 \\
1,06 \\
1,49\end{array}$ & $\begin{array}{l}0,86 \\
1,21 \\
1,71\end{array}$ & - & - \\
\hline
\end{tabular}

Примітка: К* - контроль.

Урожайність рослин селери сорту Аніта була більшою у варіантах із застосуванням гелю $(23,7$ т/га) та таблеток $(21,9$ т/га), що на 6,9 та 5,1 т/га більше за контрольний варіант, а нижчою у варіанті без внесення гідрогелю $17,5 \mathrm{~T} /$ га.

Для встановлення ступеня взаємозв'язку між змінними та їх впливу на врожайність було визначено кореляційну функцію.

У ході роботи встановлено, що існує сильний позитивний кореляційний зв'язок між урожайністю та масою надземної частини рослини $(\mathrm{r}=0,78)$, довжиною черешка $(\mathrm{r}=0,85)$, його товщиною $(\mathrm{r}=0,93)$, загальною та товарною масою $(\mathrm{r}=0,90-0,93)$.

У ході роботи можна відмітити, що такі показники, як висота розсадних рослин та товщина кореневої шийки мали середній прямий кореляційний зв'язок із урожайністю селери $(\mathrm{r}=$ 0,51-0,59). Показник кількості листків мав слабку кореляційну залежність $(\mathrm{r}=0,06)$, а кількість черешків на рослині була обернено пропорційною до їх урожайності $(\mathrm{r}=-0,51)$.

До основи оцінювання економічної ефективності запровадження окремих елементів технології вирощування селери черешкової покладено визначення вартості та собівартості продукції, умовно чистого прибутку, матеріальновиробничих витрат, рівня рентабельності. У підсумку метою вирощування овочевої продукції загалом, та селери черешкової зокрема, повинно стати одержання прибутку.

Для визначення економічної ефективності використовували типові технологічні карти вирощування селери черешкової із використанням затрат матеріально-товарних ресурсів. Ціни на насіннєвий матеріал, гідрогель, витрати на вирощування розсади, паливо-мастильні матеріали взято у середньому за 2017-2018 pp.

Оскільки ціна однієї тони товарної продукції селери черешкової за варіантами досліду є однаковою і складає 9000 грн, а врожайність різна, то вартість продукції також $\epsilon$ різною. У сорту Діамант вона становила від 151200 у контрольному варіанті, без внесення гідрогелю, до 200700 грн/га у варіанті за застосування гранул. Через вищу врожайність сорту Аніта вартість продукції, відповідно, була більшою, ніж у сорту Діамант і знаходилася на рівні 157500 213300 грн/га.

Витрати на виробництво одиниці продукції за сортами та варіантами досліду, відповідно, також були різними. Фактично усі технологічні прийоми вирощування селери не відрізнялись між собою у варіантах досліду. Різницю становила вартість самого гідрогелю, яка формувала основні витрати на виробництво. Вищими показниками витрат відзначились варіанти за застосування гранул у обох сортах (171960 грн/га).

Показник собівартості продукції розраховують як число, що залежить від витрат на виробництво й рівня врожайності, тому його значення було різним. У варіантах досліду, де застосували гідрогель у формі гелю, собівартість була нижчою, ніж у інших варіантах (Діамант 6541,9 грн/т, Аніта - 5796,6 грн/т). Собівартість одиниці продукції у контрольному варіанті та у варіантах за застосування гранул були вищими, ніж за застосуванням гелю чи таблеток (Діамант - 7711,2-8084,5 грн/т, Аніта - 7761,18188,6 грн/т). 
Під час розрахунку умовно чистого доходу спостерігали обернено пропорційні показники 3 собівартістю продукції. Вищим рівнем доходу вирізнялись варіанти, де застосували гідрогель у формі гелю: у сорту Діамант - 51620 грн/га, у сорту Аніта - 75920 грн/га.

Головним показником економічної ефективності вирощування селери черешкової є рівень рентабельності, що виражається у відсотках. Найбільш рентабельним варіантом під час вирощування селери черешкової $є$ використання гелю у сорту Аніта - 55,3 \%. Це можна пояснити високою врожайністю та відносно невеликими цінами на гідрогель. Меншу рентабельність спостерігали у контролі - 11,3 \% (через низьку урожайність) та у варіантах за застосування гранул у обох сортах - 16,7 \% у сорту Діамант та 9,9 \% у сорту Аніта. Це спричинено високими цінами на гранули.

Висновки. Як свідчать отримані дані, розсада сортів Діамант та Аніта у варіантах за застосування різних форм гідрогелю була кращою за результатами спостережень кількості діб від повних сходів до настання окремих фенологічних фаз росту та розвитку. Різниця у кількості діб між варіантами досліду становила 7-9 діб.

Було доведено, що варіанти з використанням усіх форм гідрогелю мали кращі показники висоти (+0,2-6,0 см до контролю), товщини кореневої шийки (+2,0-3,8 мм до контролю) та маси надземної частини $(+0,5-1,6$ г до контролю), ніж контрольний варіант без використання гідрогелю.

Установлено, що застосування гідрогелю під час вирощування селери черешкової позитивно впливає на біометричні показники рослини та рівень їі врожайності. Так, використання гідрогелю у формі гелю в сорту Аніта допомогло отримати 23,7 т/га якісної товарної продукції, а це - додатково 6,9 т/га до контролю.

Також виявлено, що використання гідрогелю $\epsilon$ економічно ефективним та рентабельним. Кращою рентабельністю можна відмітити варіант із використанням гелю у сорту Аніта $55,3 \%$.

\section{References}

Bolotskykh, A.S. (2005). Nastolnaia knyha ovoshchevoda. [Handbook for the grower]. Kharkiv: Folio, 2005, 487 p. [in Russian].

Bondarenko, H.L., Yakovenko, K.I. (2001). Metodyka doslidnoi spravy $\mathrm{v}$ ovochivnytstvi $\mathrm{i}$ bashtannytstvi. [Methodology of experimental work in vegetable and melon]. Kharkiv: Osnova, 369 p. [in Ukrainian].

Borosic, J. (1990). New technology of growing seed lings. Agricultural Gazette. Zagreb. № 6, pp. 121-129.

Dyduch, J., Kossowski, M. (1980). Influence of planting date on yield rasady four varieties of celery slerow on mineral soil and torfovej. Poland. Agricultura. № 35, pp. 343-350. [in English].

Hrytsayenko, Z.M., Hrytsayenko, A.O., Karpenko, V.P. (2003). Metody biolohichnykh ta ahrokhimichnykh doslidzhen roslyn i hruntiv. Kyiv: ZAT "NICHLAVA", 320 p. [in Ukrainian].

Kastori, R. (1991). Physiology of plants, Belgrade, pp. 219-220. [in English].

Markovic, P., Takac, A., Voganjac, L. (1992). Production of container seedlings. Contemporary Agriculture, № 1-2, pp. 11-14. [in English].

Pressman, E. (1997). The physiology of vegetable crops. Celery. NewYork. 1997, pp. 387407. [in English].

Ramin, A.A., Atherton, J.G. (1991). Manipulation of bolting and flower in gincelery (Apiumgraveolens L. var. dulce) II. Juvenility. J. Hort. Sci, № 66, pp. 709-717. [in English].

Ramin, A.A., Atherton, J.G. (1991). Manipulation of bolting and flower in gincelery (Apiumgraveolens L. var. dulce) III. Effects of photoperiod and irradiance. J. Hort. Sci, № 69, pp. 861-868. [in English].

Ulianych, O.I. (2018). Biolohichni osoblyvosti i vyroshchuvannia maloposhyrenykh ovochiv. [Biological features and growing of uncomplicated vegetables]. Uman: Vydavets "Sochinskyi M. M.“, 282 p. [in Ukrainian]. 